\title{
Rethinking Human Development Based on Ar Ra'd Verse 11: How Can Preferences Influence Human Development?
}

\author{
An'im Kafabih', Muhammad Dandy Alif Wildana ${ }^{2}$ \\ ${ }^{1}$ Faculty of Economics and Business, Diponegoro University, J1. H. Prof. Soedarto, SH, Tembalang, Semarang, \\ Indonesia,kafa@lecturer.undip.ac.id. \\ ${ }^{2}$ Faculty of Economics and Business, Brawijaya University, Jl. MT. Haryono no.165, Malang, Indonesia, \\ dandyalif.feb.ub@ub.ac.id.
}

\begin{abstract}
As human is the centre of development process, it is important to consider preferences of human behavior whether they prefer to change themselves or not. This explanation is inspired by Qur'an surah Ar Ra'd verse 11 that can be interpreted as the set of preferences which might influence someone's state of condition. However, human development index which is widely used indicator for development study do not consider preference as the main factor of development. Therefore aim of this study is to examine interpretation of that surah whether set of preferences that consist of trust, altruism, patience, risk taking, and negative reciprocity, can influence the state of human development. This research Uses Linear Probability Model (LPM) which is estimated by OLS with 76 countries as observation. The result shows that altruism, patience and risk taking can influence human development significantly, whereas trust and negative reciprocity are not significant. Trust is not significant because there might be a condition of distrust economic activities, rather than trust, that signaled by complete contractual arrangement, whereas non significant of negative reciprocity might because the costly punishment opportunity to punish someone as the form of negative reciprocity, therefore people that think rationally will not take the revenge to others.
\end{abstract}

Keywords: Ar Ra'd verse 11, human development, interpretation, preferences.

\begin{abstract}
Abstrak. Sebagaimana manusia merupakan pusat dari proses pembangunan, sangat penting untuk memperhatikan preferensi dari perilaku manusia, apakah mereka memiliki kecenderungan untuk mengubah dirinya atau tidak. Penjelasan ini terinspirasi dari Qur'an surat Ar Ra'd ayat 11 yang dapat diinterpretasikan sebagai berbagai preferensi yang mungkin dapat memengaruhi kondisi seseorang. Namun, index pembangunan manusia yang sering digunakan dalam studi pembangunan tidak mempertimbangkan preferensi sebagai faktor utama dari pembangunan. Oleh karena itu, tujuan penelitian ini adalah untuk menguji interpretasi dari surat tersebut apakah preferensi, yang terdiri dari kepercayaan, altruisme, kesabaran, pengambilan risiko, dan timbal balik negatif, dapat memengaruhi pembangunan manusia. Penelitian ini menggunakan Linier Probability Model (LPM) dengan 76 negara sebagai jumlah observasi. Hasil penelitian menunjukkan bahwa altruisme, kesabaran dan pengambilan risiko dapat memengaruhi pembangunan manusia, namun tidak pada kepercayaan dan timbal balik negatif. Tidak signifikannya variabel kepercayaan karena adanya kemungkinan aktivitas ekonomi yang berdasarkan ketidakpercayaan daripada aktivitas ekonomi yang berdasar kepercayaan. sedangkan timbal balik negatif yang tidak signifikan dikarenakan besarnya biaya untuk menghukum balik seseorang, sehingga seseorang yang berpikir rasional akan memilih untuk tidak melakukan balas dendam pada orang lain.
\end{abstract}

Kata kunci: Ar Ra'd ayat 11, interpretasi, pembangunan manusia, preferensi.

\section{INTRODUCTION}

Mirakhor and Askari (2010) asserted the Mahbub ul Haq's perspective about economic development where it must considers much about human as the end of development process. Since development is translated as the process of improving the quality of all human lives and capabilities by raising people's level of living, self-esteem and freedom (Todaro and Smith, 2012), all that process of development is related to the change of someone's condition. Furthermore, some studies also try to formulate measurement to delineate the whole picture of that condition. One study that is widely used 
to compare condition of socioeconomic development is conducted by United Nations Development Program (UNDP), namely human development reports (Todaro and Smith, 2012).

The main highlight of that report is human development index (HDI) that portrays the development condition in some countries based on several indicators. Gamlath (2013) explains that indicators of HDI are income, health and knowledge whereas Income is an important indicator among these three. That is because as Todaro and Smith (2012) explained, countries with higher income can invest more on health and education making level of HDI become higher, even though that pattern is different among countries. Intuitively, the lesser the intensity of poverty, the greater is the level of human development (Datta and Singh, 2019). As human development is related to poverty as one indicator of welfare, knowing level of HDI hopefully will help policymakers to formulate proper policies to enhance the condition of society in their countries.

Aydin (2017) explains that HDI is created based on the notion of human capabilities proposed by Amartya Sen. For Sen's understanding, development can be understood by using his capability approach where development is related to enlarging freedom of choice and opportunities (Croes et al., 2021). However, in Islamic viewpoint, human development can be found in Qur'an Surah Ar Ra'd verse 11 as the state of condition of human being that can be affected by preference. As preference change, human condition will also change, or the state of human development level would be change. This simple interpretation of the surah then provide new hypothetical concept that should be tested where set of preferences can significantly affect human development of somebody. As human condition index is not consider the importance role of preferences to the process of development, and also still there is no previous studies that focuss on the interpretation of that surah and its relation to human development, the specific aim of this paper is to study interpretation of Surah $A r R a$ ' $d$ verse 11 in which at a glance explains that set of preferences can influence the condition of people that can be depicted by level of human development index.

Preference as the main determinant of human development is a latent variable, based on interpretation of Surah Ar Ra'd Verse 11, has an influence to human development. In the previous studies, most of determinants of human development are based on macro and non-latent variables. Hafner and MayerFoukes (2013), for instance, they find that fertility is negatively related with human development in developing countries, Sarkodie and Adams (2020) find that income inequality can reduce human deveopment, whereas Croes et al. (2021) find that economic growth as a main channel to support human development expansion. Others variables have been studied related to HDI such as Datta and Singh (2019) that conducted reseach on how financial inclusion index (FII) associates with HDI, Sinha and Sengupta (2019) studied the impact of natural resource rent on HDI, Yolanda et al. (2020) on gini ratio and crime to poverty rate with intervening variable is HDI and da Silva et al. (2021) that studied funding deficit on HDI.

The aim of this study is to examine interpretation of Surah Ar Ra'd verse 11. The interpretation then explaining that preference might can influence human development. Preference here includes trust, altruism, patience, risk taking, and negative reciprocity. As development study is rare to include analysis of preference, this study will theoretically benefit the study of development by boardening the perspective using lens of preference. Furthermore, variables such as trust, altruism, patience, risk taking, and negative reciprocity lies in micro level, or in human, therefore this study will reflect the condition of human behavior on how to increase their level of development.

Furthermore, this paper is structured as follows. Section 2 comprised of theoretical background and previous literature reviews and followed by research method in section 3 that describes about the approach of this research, sources of data, and instruments to process the data. Then section 4 presents results followed by discussions and the section 5 presents conclusion. 


\section{LITERATURE REVIEW}

\section{Role of Religion on Developmental Study}

Todaro and Smith (2012) explain that identificating some issues of development such as poverty, inequality, environmental decay as problems that must be eliminated are based on value judgement. Different groups of people agreed that these problems must be resolved and become the desirable goals. That agreement is the main evidence that these goals ultimately come from subjective or normative value judgement about what should be. This explains that study of development is inseparable from the role of value.

For Schwartz (1994), value is "desirable transituational goals, varying in important, that serve as guiding principle in the life of a person or other social entity". Value that serves guiding principle for someone is come from many sources. Based on institutional economics viewpoint, value is one part of informal institutional framework where Kurtulmus and Warner (2016) explain that religion can create culture that is significantly important source for informal institutional frameworks from which value can be derived. Therefore, based on that explanation, religion is a source of value that a someone hold as the guiding principle in his life, and plays an important role to the study of development.

That statement is supported by several scholars such as Palanca (1986) that explain about noneconomic factor such as religion, that gives motivational and/or proper institutional setting in the most instances of development, Deneulin and Rakodi (2010); Bhalotra et al. (2014); Basedau et al. (2015); and Deneulin and Zampini-Davies (2017).

\section{Determinant of Human Development}

A study that is used to compare condition of socioeconomic development is human development reports with its Human Development Index (HDI) (Todaro and Smith, 2012). Gamlath (2013) explains that HDI proposed by UNDP consist of three indicators, viz income, health and knowledge. As income per capita rise, HDI tends to rise. When countries become wealthier, the investment in knowledge and healthcare will increase as well, thus making HDI increase even though that pattern differs between each others (Todaro and Smith, 2012). Therefore, income become an important indicator in HDI.

Falk et al. (2018) on the Quarterly Journal of Economics wrote "global evidence on economic preferences" where basically theories of human behavior in economics assume that set of preferences are the driving force of human decision making. Time preference, risk taking, positive and negative reciprocity, altruism, and trust are some preferences considered in Falk et al. (2018) study.

In Islamic point of view, Quran surah Ar Ra'd verse 11 stated “...Truly God alters not what is in a people until they alter what is in themselves..." (Nasr et al., 2015). Based on that verse, Nasr et al. (2015) comment that God will not alter condition of people until they themselves bring about changes in their action and lives. Based on that commentary, one keyword which should be taking into account is "action". If people's decision making can be reflected in their action, based on Falk et al. (2018)'s explanation, it is reasonable to argue that set of preferences act as driving force of human decision and further implemented in their actions. Their action then can determine their state of condition which can be portrayed in level of human development. Based on that interpretation, then it is reasonable to conclude that preferences will change people's decision-making process, thus it will be reflected in their actions and make the change in human development.

In short, Falk et al. (2018) includes preferences as several variables that is fit to the virtue of Islam such as trust, altruism, patience, risk taking, positive reciprocity, and only one that is not fit to the virtue of Islam, viz negative reciprocity as it similar to taking revenge. 


\section{Trust}

In their online appendix, Falk et al. (2018) explained that self-assessment of trust is that people have only the best intentions. In the context of New Institutional Economics, Suzuki and Miah (2016) stress that trust is essential element that has a greater impact on transaction cost. Therefore, best intention among people will reduce transaction costs such as written contract, cost of monitoring and enforcing contract, cost of finding the right partners, and so on. As the cost reduced, income will be higher, cateris paribus. As income is part of HDI, then increasing level of trust will increase level of human development depicted by HDI.

\section{Altruism and positive resiprocity}

Saito (2015) defines altruism as a willingness to benefit others, even at one's own expense. Linear on that definition, altruism in Falk et al. (2018) is implemented in a hypothetical situation as a question: "today you unexpectedly received 1000 euro. How much of this amount would you donate to a good cause?". This question indirectly try to reveal altruistic behavior of someone. Theoretically, Aydin (2017) proves that altruistic society stimulates greater social well-being rather than capitalism, cateris paribus. Altruism also highly related to the state of sympathy where Mantell (2018) explains that "sympathy arise when someone is interested in improving somebody else's condition, ...". From that explanation at glance, there would be any relation between altruism and human development. Furthermore, Falk et al. (2018) reveal behavior of someone that categorised as positive reciprocity by willingness to give present with has different value (no present, present worth 5 euro/10 /20/ untill 30 euro). Based on the description, positive reciprocity is almost the same as altruism but with fundamental difference as explained by Fehr and Gachter (2000) where altruism is a form of unconditional kindness and reciprocity is a in kind response to benefical acts.

\section{Patience}

Lexically, patience refers to the quality of waiting calmly, the ability to endure, the state of steadiness or perseverance in a performance of a task without complaining (Yaroub et al., 2019). In Qur'an, patience is mentioned ninety times in different contexts (Leaman, 2006). Al-Isfahani devides two kinds of patience : physical patience that endure difficulity such as carrying heavy stone, and spiritual patience which enduring calamity, avoid luxury, and respect secrery (Leaman, 2006). Falk et al. (2018) reveal patience as the willingness of someone to give up something that is benefical for him today in order to benefit more from that in the future. Cysne (2006) presents a paper that shows positive relation between patience and income. Empirically, Cysne shows that patient workers who reject less favourable wage offer end up receiving higher average wage in the long run.

\section{Risk taking}

Risk is a measurement of uncertainty about the frequency and consequences of an unacceptable event (Al-Saati, 2003). People that taking risk for business for instance, can identify some important variables about the business to predict probability of being success and failure because of competitive business environment. Risk can be shared to minimise its impact, and also if people getting profit, then the profit can be shared. The term of this concept is known as profit and loss sharing. People that taking risk and implement profit and loss sharing concept can minimise impact of loss.

In one study conducted by Maski et al. (2018), profit and loss sharing can minimise level of inflation. Inflation can be categorised as risk of loss, especially loss of purchasing power. Slightly different study also prove that taking risk has a positive sign on entrepreneurial competencies (Al Mamun and Fazal, 2018). As competencies getting higher, human development will be higher. When people fail on one occasion, they will learn what is the factor of their failure, gaining new knowledge to prevent the same thing occur in the future. The accumulation of new knowledge they gather, make human development to go up.

However, Falk et al. (2018) explain the behavior of risk taking of someone by making someone to chose among the two condition: a sure payment of a particular amount of money, or a draw that might bring him an equal chance of getting amount $\mathrm{x}$ or getting nothing. Based on that condition, as people 
take a draw, it can be categorised as gambling that is prohibited in Islam (Askari et al., 2015). Gambling is a different category of taking risk explained in paragraph before. Basically, probability of success and failure in gambling can be computed, but as the probability of failure is presented, then that probability is fixed and cannot be minimised or shared.

In addition Uddin (2015) explains that gambling is a literal meaning of maysir that is prohibited in Islam. Maysir refer to the easy acquisition of wealth by chance, whether or not it deprives the other's right. Nooteboom (2015) explains that betting as a form of risk-taking are seriously endangering, among others, health. Eadington (2003) notes that one adverse impact of gambling is pathological gamblers. Eadington (2003) notes that one adverse impact of gambling is pathological gamblers. Pathological gambling or "gambling disorder" is categorised as substance-related and addictive disorder where one diagnostic criteria is somebody "needs to gamble with increasing amounts of money in order to achieve the desired excitement". In empirical investigation, gamblers significantly increase their bet sizes after win streaks, with the largest increase after three wins in a row (Salaghe et al., 2020). Based on that slight explanation, as people taking risk more frequently in the form of gambling, the probability of getting addictive disorder is high. As health is one indicator of human development, gamblers who take risk by gambling will lower their human development.

Gambler can be categorised as risk lovers who has a convex utility function. The slope would be steeper as wealth increases (Varian, 2014). This means as gamblers has greater wealth, they will gamble more frequently because their utility of the expected value of wealth is greater than the expected utility of wealth (utility of doing gambling). As their utility is a part of their preference, the higher they involved in gambling, the higher probability of their wealth is placed in danger situation. Based on this situation, there might be any relation between risk taking in the form of gambling to income as one important of human development index.

\section{Negative reciprocity}

Falk et al. (2018) reveal behavior of someone that categorised as negative recipocity by the "willingness to punish someone who treat you unfairly". Negative reciprocity is like taking revenge of someone because doing unfairly. In Islam, taking revenge is explained in Surah Al-Nahl verse 126 where Allah Says "And if you would punish, then punish with the like of that wherewith you were punished. But if you are patient, then that is better for the patient" (Nasr et al., 2015). Interesting study has been conducted by Caliendo et al. (2012) where they found that "a high willingness for revenge the strongest form of negative reciprocity - increase the probability of exiting entrepreneurship. As people exit from entrepreneur, their income will reduce, this will probably reduce the human development index. Therefore people that has high tendency to act negative reciprocity will probably at risk of losing their income because they will probably exit from entrepreneurhip, making probability of human develipment index become lower.

\section{METHOD}

Prophet Muhammad (PBUH) Said in a hadith that "Ikhtilaf ummati rahmah" or difference of opinion in my community is (a sign of) the bounty of God (Azizy, 1995). Different opinions or ikhtilaf among scholars has, in fact, characterized Islamic legal thought where ikhtilaf will always emerge as the consequence of excercising ijtihad (independent interpretation) (Azizy, 1995). Furthermore, related to this paper, this study is conducted with the main goal is to examine the interpretation of surah Ar Ra'd verse 11 that, at a glimpse, shed light on the relation between preference and human development.

To achieve the goal, this research uses a quantitative approach with 76 country level cross-sectional data as sample size. This sample size is enough to be analysed as McClave and Sincich (2018) explain that the minimum sample size $(n)$ to make sample distribution aproximately normal is 30 observation (n). Furthermore, in this research, preference is independent variable that consist of trust, altruism, patiece, risk taking, positive reciprocity, and negative reciprocity. These all are gathered from 
referring to Falk et al. (2018)'s article (the data are all published in 2018). The dependent variable is human development which is proxied by Human Development Index (HDI). The data is gathered from Human Development reports (2019) (all the data are in year of 2018). All variables are country level variable but can be used to interpret average behavior and circumstance of people within the country.

This study uses Linear Probability Model (LPM) estimated by OLS, where for dependent variable, 1 means probability of being categorised as very high human development (HDI $\geq 0.894$ ), and 0 is otherwise. This study do not use positive reciprocity as independent variable because of its identical definition to altruism, therefore problem of multicollinearity can be reduced. Full model in this study is presented as follows

$$
Y_{i}=\alpha+\beta_{1} X_{1 i}+\beta_{2} X_{2 i}+\beta_{3} X_{3 i}+\beta_{4} X_{4 i}+\beta_{5} X_{5 i}++\mu_{i}
$$

Where, $\mathrm{Y}$ is HDI, $\mathrm{X}_{1}$ is trust, $\mathrm{X}_{2}$ is altruism, $\mathrm{X}_{3}$ is patience, $\mathrm{X}_{4}$ is risk taking, $\mathrm{X}_{5}$ is negative resciprocity, $i$ stands for country as cross section observation data, $\alpha$ is intercept, $\beta_{1 \ldots 5}$ stands for coefficient, and $\mu$ is error term. Operational definition of each variables is served in Table 1. Because the nature of data in this research is cross section that highly related to heteroskedastic problem, this paper employs white robust standar errors to obtain standard errors efficiently (Gujarati and Porter, 2008). This paper also employs the other classical assumption such as autocorrelation, multicollinearity, and normality to obtain Best Linier Unbiased Estimators (BLUE).

Table 1 Operational variables

\begin{tabular}{|c|c|c|c|}
\hline Dependent variable & Definition & Measurement & Source of data \\
\hline $\begin{array}{l}\text { Human Development } \\
\text { Index (HDI) }\end{array}$ & $\begin{array}{l}\text { Index that consis of } 3 \text { indicator: } \\
\text { Income per capita, health and } \\
\text { education to determine } \\
\text { socioeconomics development } \\
\text { (Todaro and Smith, 2012; Gamlath, } \\
\text { 2013) }\end{array}$ & $\begin{array}{l}1 / 3 \text { (income } \\
\text { index) }+1 / 3 \text { (life } \\
\text { expectancy } \\
\text { index) }+1 / 3 \\
\text { (education index) }\end{array}$ & $\begin{array}{l}\text { Human } \\
\text { Development Report } \\
(2019)\end{array}$ \\
\hline Independent Variable & Item description & Weight & Source of Data \\
\hline Trust & People have only the best intentions & 1 & Falk et al. (2018) \\
\hline Altruism & $\begin{array}{l}\text { Self-assessment: Willingness to } \\
\text { give to good causes } \\
\text { Donation decision }\end{array}$ & $\begin{array}{l}0.365 \\
0.635 \\
\end{array}$ & Falk et al. (2018) \\
\hline Patience & $\begin{array}{l}\text { Intertemporal choice sequence using } \\
\text { staircase method } \\
\text { Self-assessment: Willingness to } \\
\text { wait }\end{array}$ & $\begin{array}{l}0.712 \\
0.288\end{array}$ & Falk et al. (2018) \\
\hline Risk taking & $\begin{array}{l}\text { Draw choice sequence using } \\
\text { staircase method } \\
\text { Self- assessment: Willingness to } \\
\text { take risks in general }\end{array}$ & 0.527 & Falk et al. (2018) \\
\hline Negative reciprocity & $\begin{array}{l}\text { Self-assessment: Willingness to } \\
\text { take revenge } \\
\text { Self-assessment: willingness to } \\
\text { punish unfair behavior toward self } \\
\text { Self-assessment: willingness to } \\
\text { punish unfair behavior toward } \\
\text { others }\end{array}$ & 0.313 & Falk et al. (2018) \\
\hline
\end{tabular}

Source : Researchers from many sources, 2020.

Based on Human Development Report (2019), HDI is computed at the country level, and using capability approach to measure capability to live long and healthy life to acquire knowlegde and income to maintain the live. Besides country level computation, the result of HDI can be used to 
interpret average condition of people within the country. Furthermore, preference variable is basically a individual based variable, then Falk et al. (2018) compute that individual-based variable into country level average by weighting individual-level data with the sampling weights provided by Gallup (see Table 1).

\section{RESULTS AND DISCUSSION}

\section{Results}

\section{Descriptive statistics}

This section presents the empirical result of of estimated model beginning with descriptive statistical analysis to ascertain characteristics of data (Sarkodie and Adams, 2020). Before that, Table 2 below shows some countries that is categorised as 1 or "very high human development (HDI $\geq 0.894$ )", and 0 , otherwise. Based on Table 2, about $56.5 \%$ or 43 countries are not categorised as "very high human development ", and 33 is very high human development. Furthermore, descriptive statistical analysis is presented in Table 3. Table 3 reveals that among 76 countries which are observed. The highest point is people in Switzerland by 0.946 whereas people of Malawi is the lowest country's HDI value by only 0.485 . Furthermore, the median value of HDI is 0.768 with range is 0.461 . Standard deviation is 0.129 which shows the minimum dispersion of the data that is analysed.

Among countries observed, Table 3 also shows the average value of trust that is very low with only 0.022. With range 1,315, people of Egypt have the very high level of trust among others with 0.609 and for the lowest level of trust by -0.706 is people of Uganda. Furthermore, with the average value of altruism among countries is -0.038 and the average value of patience is -0.003 , people of Bangladesh show the most altruistic people compared to the other countries whereas people of Sweden have highest level of patience. In reverse, the Chezh people have the lowest level of altruism and Nicaraguans for the lowest level of patience.

Table 2 Descriptive statistics of variables

\begin{tabular}{|c|c|}
\hline $\begin{array}{c}\text { Countries categorised as } 1 \text { or "very high } \\
\text { human development" }\end{array}$ & Countries categorised as 0 , otherwise \\
\hline $\begin{array}{l}\text { Argentina, Australia, Austria, Canada, Chile, } \\
\text { Colombia, Croatia, Czech Republic, Estonia, } \\
\text { Finland, Frence, Germany, Greece, Hungary, } \\
\text { Israel, Italy, Japan, Kazakistan, Lithuania, } \\
\text { Netherland, Poland, Portugal, Romania, } \\
\text { Russia, Saudi Arabia, South korea, Spain, } \\
\text { Sweden, Switzerland, Turkey, United Arab } \\
\text { Emirates, UK, US }\end{array}$ & $\begin{array}{l}\text { Afghanistan, Algeria, Bangladesh, Bolivia, } \\
\text { Bosnia Herzegovina, Bostwana, Brazil, } \\
\text { Cambodia, Cameroon, China, Costa Rica, } \\
\text { Egypt, Georgia,Ghana, Guatemala, Haiti, } \\
\text { India, Indonesia,Iran, Iraq, Jordan, Kenya, } \\
\text { Malawi, Mexico, Moldova, Morocco, } \\
\text { Nicaragua, Nigeria, Pakistan, Peru, } \\
\text { Philippines, Rwanda, Serbia, South Africa, Sri } \\
\text { Lanka, Suriname, Tanzania, Thailand, Uganda, } \\
\text { Ukraine, Venezuela, Vietnam, Zimbabwe. }\end{array}$ \\
\hline Count: 33 & Count: 43 \\
\hline
\end{tabular}

Source : Human Development Report, 2019 (processed by researcher). 
Table 3 Descriptive statistics of variables

\begin{tabular}{ccccccc}
\hline \multirow{2}{*}{$\begin{array}{c}\text { Descriptive } \\
\text { statistics }\end{array}$} & $\begin{array}{c}\text { HDI } \\
\text { (dummy) }\end{array}$ & Trust & Altrusim & Patience & $\begin{array}{c}\text { Risk } \\
\text { Taking }\end{array}$ & $\begin{array}{c}\text { Negative } \\
\text { resiprocity }\end{array}$ \\
\hline Mean & 0.434 & -0.022 & -0.038 & -0.003 & 0.013 & 0.013 \\
\hline Median & 0 & -0.081 & -0.097 & -0.093 & -0.020 & 0.004 \\
\hline Range & 1 & 1.315 & 1.846 & 1.684 & 1.763 & 1.228 \\
\hline Minimum & 0 & -0.706 & -0.940 & -0.613 & -0.792 & -0.489 \\
\hline Maximum & 1 & 0.609 & 0.906 & 1.071 & 0.971 & 0.739 \\
\hline $\begin{array}{c}\text { Standard } \\
\text { Deviation }\end{array}$ & 0.499 & 0.278 & 0.343 & 0.370 & 0.302 & 0.275 \\
\hline Count & 76 & 76 & 76 & 76 & 76 & 76 \\
\hline
\end{tabular}

Source : Falk et al., 2018 and Human Development Report, 2019 (processed by researcher).

People of South Africa and Croatia successively have the highest average of risk taking people and negative resiprocity. The former has the value of risk taking by 0.971 whereas the latter is 0.739 . People with the lowest level of risk taking is people of Portugal ( -0.792) whereas the lowest level of negative resiprocity is people of Guatemala (-0.489). In a nutshell, this statistical descriptive analysis also reveals that trend in many countries shows very low level of preference in trust, altruism and patience, whereas among countries observed, on average people prefer to take risk and doing negative resiprocity.

\section{Estimation result}

Table 4 figures estimation result in this study. Overall, $\mathrm{R}^{2}$ in this Linier Probability Model (LPM) is 0.3997. This result is appropriate with what Gujarati and Porter (2008) explain that in most practical application, $\mathrm{R}^{2}$ of LPM has range between 0.2 to 0.6 . Furthermore, from 5 independent variables, three variables are found to be significant in $1 \%$ level of significance, whereas 2 variables are not significant in any level.

Table 4 Estimation result

\begin{tabular}{|c|c|c|c|}
\hline No & Independent Variables & Coefficient & Std. Error \\
\hline 1 & Trust & 0.197344 & 0.164361 \\
\hline 2 & Altruism & $-0.319330 * * *$ & 0.120219 \\
\hline 3 & Patience & $0.687178 * * *$ & 0.096225 \\
\hline 4 & Risk Taking & $-0.483824 * * *$ & 0.133878 \\
\hline \multirow[t]{7}{*}{5} & Negative Reciprocity & 0.243528 & 0.188734 \\
\hline & $\mathrm{C}$ & 0.431855 & 0.046325 \\
\hline & \multicolumn{3}{|c|}{ Dependent Variable : HDI (DUMMY) } \\
\hline & Classical Assumption & Prob. F-stat & \\
\hline & Autocorrelation & 0.589 & \\
\hline & Heteroscedassticiity & 0.376 & \\
\hline & Ramsey RESET & 0.517 & \\
\hline
\end{tabular}

***) $1 \%$ level of significant

Source: Data processed by Eviews, 2020. 
Table 5 Collinearity result

\begin{tabular}{crrrrc}
\hline & X1_TRUST & X2_ALTRUISM & X3_PATIENCE & X4_RISKTAKING & X5_NEGRECIP \\
\hline X1_TRUST & $\mathbf{1 . 0 0 0 0 0 0}$ & 0.272735 & 0.189909 & -0.061453 & 0.159890 \\
X2_ALTRUISM & 0.272735 & $\mathbf{1 . 0 0 0 0 0 0}$ & -0.010385 & -0.015175 & -0.131952 \\
X3_PATIENCE & 0.189909 & -0.010385 & $\mathbf{1 . 0 0 0 0 0 0}$ & 0.230358 & 0.258087 \\
X4_RISKTAKING & -0.061453 & -0.015175 & 0.230358 & $\mathbf{1 . 0 0 0 0 0 0}$ & 0.192764 \\
X5_NEGRECIP & 0.159890 & -0.131952 & 0.258087 & 0.192764 & $\mathbf{1 . 0 0 0 0 0 0}$ \\
\hline
\end{tabular}

Source : Researcher (2020)

The model is free from autocorrelation and heteroscedasticity. Ramsey RESET also shows the model is not misspecified. In addition, Table 5 shows correlation coefficient among independent variable. It shows low correlation among independent variable which all correlation coefficient is under 0.7 as the maximum correlation as the rule of thumb explained by Ariefianto (2012). This result shows that there is no substantial problem of multicollinearity.

\section{Discussion}

In general, based on estimation result, figure 1 below shows probability of people in countries which is not categorised as 1 or "very high human development" to be categorised as very high human development given existing condition of independent variables, cateris paribus.

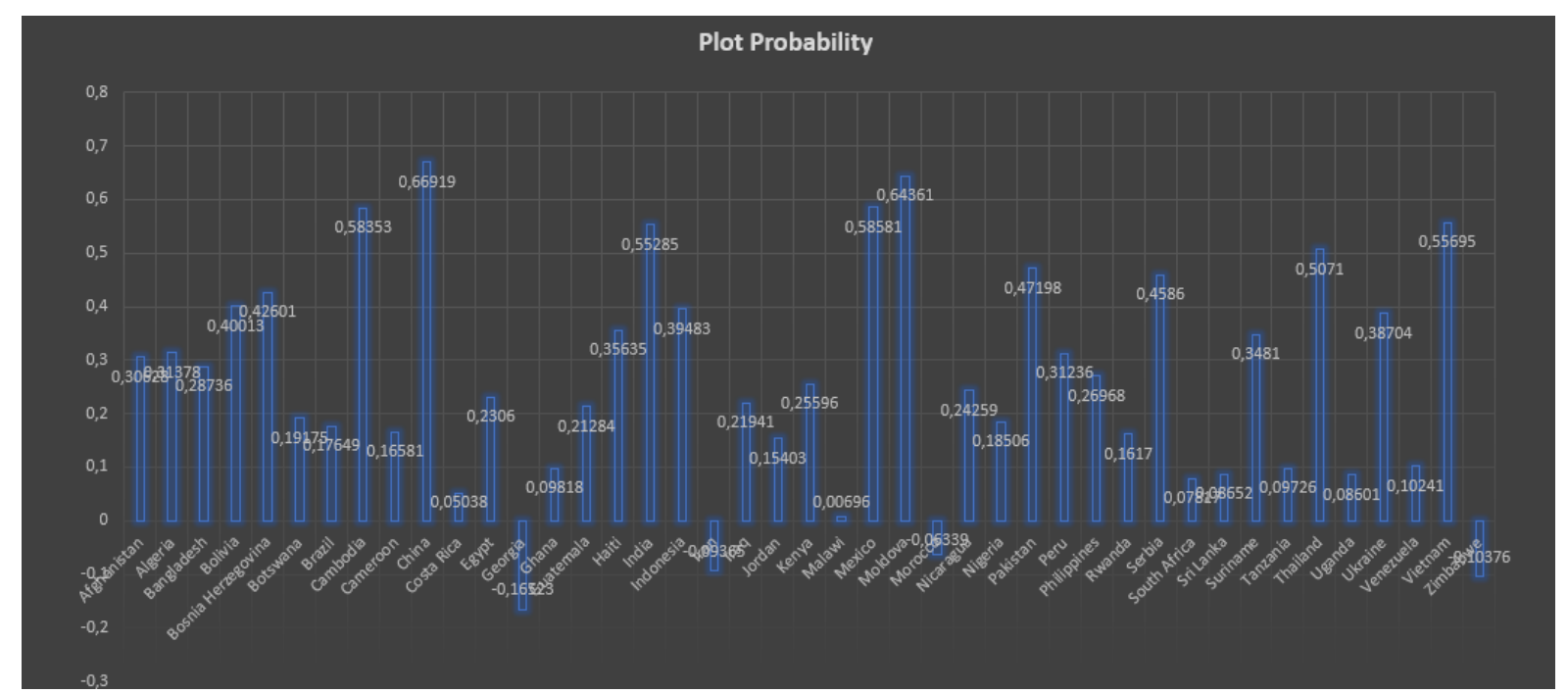

Source: Researchers' estimation result (2021)

Figure 1 Probability of people in countries

Based on above data, China have the highest probability to be categorised as "very high human development" by about $66.9 \%$ followed by Moldova (64.4\%), Mexico (58.6\%), Cambodia (58.3\%) and Thailand $(50.7 \%)$. That big 5 countries shows that, given existing independent variables in this study, people in that countries have highest probability to be more developed. However, that big 5 is not Muslim countries or countries that have majority of Muslim people. Others discussion is about the relationship between independent variables to dependent variable.

\section{Trust}

The insignificant result in this paper might indicate that the role of trust is not really taken into account in human development. In an essay explained by Laffont and Martimort (2002) in Hadfield (2008), the effectiveness of contract law is critical to the growth of economic activity because contractual mechanisms are designed to align the interests of principal and agent to achieve efficient production. As economic activities will produce income and income is one important thing in

AL-MUZARA'AH Special Issue 2022 
computation of human development, then Hadfield (2008) indicates that contract is important thing in human devlopment.

Furthermore, in metropolis cities for instance, it is hard to trust others people they first meet, therefore people making business will use contractual agrement. This argument is supported by Lumineau (2014) explaining that set of contractual control and coordination can affect the degree of trust and also distrust. Herold (2010) also explains that the complete set of contract might be a signal of distrust, therefore when trust is important in some non-contractible part of relationship, a principle may leave the contract incomplete, rather than showing the distrust by completing the contract.

Based on above explanation, the not significant trust variable might indicate a distrust economic activities, rather that trust economic activities. This then lead to the insignificant of trust variable in influencing human development.

\section{Altruism}

Altruism variable shows negative sign and statistically significant. This result implies that a 1 percentage point increase in altruism will lead on average to about 0.32 decrease in probability of people in a country to be categorised as "very high human development" (the interpretation follows Gujarati and Porter, 2008). As altruism is the same concept as sedekah (voluntary almsgiving),the interpretation contradicts with the value of Islam where Kailani and Slama (2020) explain that one can receive from the God multiple material rewards when performing sedekah. That is the virtue of sedekah (Kailani and Slama, 2020).

As Ashraf and Bandiera (2017) explained in their formal model, the effort someone devotes to altruistic task, can produce social welfare, and altrusim as an asset can grow proportionally because of that effort. This means that altruistic act cannot increase level of development in someone but someone's effort devoted to altrusitic tasks $(u)$ can increase social welfare in the period it is exerted and the remaining (1-u) will accumulate in the next period as the altruistic capital. This explanation is depicted in the negative sign of altruism variable where the model only campture decreasing income of someone because he/she donates part of his money to others as a form of altruistic task.

The regression result then reveal at least two weaknesses in this study especially on altruism variable. First, as in Qur'an Surah Al Baqarah verse 261 spotlights the multiplied result of spending wealth in the way of Allah (sedekah), this paper cannot capture that "multiplied award from God"as it take many forms of award from material to non-material and also on what time that award is given as it can be given not only in present time but also probably in the future. Second, as Ashraf and Bandiera (2017) explained, the model used in this study is limited where it cannot capture level altruistic capital accumulation, and also increasing effect of social welfare resulted from doing altruistic tasks.

\section{Patience and risk taking}

Patience shows positive and significant result statistically whereas risk taking shows negative sign. This result implies that a 1 percentage point increase in patience will lead on average to about 0.69 increase in probability of people in a country to be categorised as "very high human development" whereas, a 1 percentage point increase in risk taking will lead on average to about 0.48 decrease in probability of people in a country to be categorised as "very high human development", other things being the same.

The best explanation on how patience influences human development comes from Sheikh (2008) in Yaroub et al., (2019). He explains that the state of sickness and tribulation are the situation that bring opportunity for man to earn reward through patience and steadfastness. In a practical situation, patience is important in doing business successfully. Myers (2017) explains that patience is really a virtue in business and impatience condition make someone looks desperate and a ultimate selfsabotage. Patience is a core to obtain and develop skill, builing a relationship, or launch a business initiative that takes many time (Myers, 2017). 
Furthermore, risk taking shows negative sign. As risk taking in this paper adopts Falk et al. (2018)'s article, the risk taking variable is categorised as gambling where has the probability of getting health issue (pathological gamblers) and also probability to face high risk of default as someone doing gambling. This slight hypothetical prediction is depicted by the negative sign of risk taking, making people who doing gamble has higher probability to get health issue and default relating to their wealth. Furthermore, the probability of that people categorised as very high human development will significantly decrease.

\section{Negative reciprocity}

The insignificant result of negative reciprocity variable means that this variable is not really taken into account in the process of human development. In Islam, taking revenge is explained in Surah Al-Nahl verse 126 where Allah Says "And if you would punish, then punish with the like of that wheremwith you were punished. But if you are patient, then that is better for the patient" (Nasr et al., 2015). From that verse, people are allowed to punish other people with the like of what others people inflicted them.

Fehr and Gachter (2000) stated about negative reciprocal in the context of public good game where free riders can be retaliated if other people have opportunity to retaliate them and have access to information on who do not contribute to public goods. However, they further explained that people who do negative reciprocal will face costly punishment opportunity to punish the free riders. Based on that explanation, as income is an important part of human development, what people do, especially the act of negative reciprocity will affect income of others, thus decrease human development. Furthermore, taking revenge on each other will result in never ending loop of revenge, and will significantly lower human development on both sides. Therefore, insignificant negative reciprocity variable portray the cost of taking revenge. The cost is not limited to money, but may include time, effort, mind, negative consequences and so on. Even though people have the opportunity to revenge, they will not do so, because of the costs that entails the act of revenge maybe too costly to bear.

\section{CONCLUSION}

The goal of this study is to reveal whether preferences can affect the state of human development. that aim is inspired by surah Ar Ra'd verse 11 that can be interpreted as the set of preference which might influece someone's state of condition. As the condition of someone can be depicted by human development index, this study want to examine that interpretation whether set of preferences can influence the state of human development. Set of preferences consist of trust, altruism, patience, risk taking, and negative reciprocity. By using Linier Probability Model (LPM), the result shows that altruism, patience and risk taking is significantly affect human development, whereas trust and negative reciprocity are not significant statistically.

The non significant effect of trust might be explained by state of distrust economic activities that signalled by complete contractual arrangement meanwhile, the non significant negative reciprocity variable might because the costly punishment opportunity to punish someone as the form of negative reciprocity, therefore people that think rationally will not take the revenge to others. Based on all result, it is better to improve analysis of human development based on something that is not considered as "materialistic" and based on the result, something important that can be considered as analysis of human development is the state of patience.

\section{REFERENCES}

Al Mamun, A. \& Fazal, S. A. (2018). Effect of entrepreneurial orientation on competency and microenterprise performance. Asia Pacific Journal of Innovation and Entrepreneurship, 12(3), 379398. 
Al-Saati, A. (2003). The permissible gharar (risk) in classical Islamic jurisprudence. Journal of King Abdulaziz University: Islamic Economics, 16(2), 3-19.

Ariefianto, M. D. (2012). Ekonometrika: Esensi dan Aplikasi dengan Mengunakan Eviews. Jakarta (ID), Erlangga.

Ashraf, N. \& Bandiera, O. (2017). Altruistic capital. American Economic Review: Paper \& Proceedings, 107(5), 70-75.

Askari, H., Iqbal, Z. \& Mirakhor, A. (2015). Introduction to Islamic Economics: Theory and Application. Solaris (SG), John Wiley \& Sons Singapore.

Aydin, N. (2017). Islamic vs conventional human development index: Empirical evidence from ten Muslim countries. International Journal of Social Economics, 44(12), 1562-1583.

Azizy, A. Q. (1995). Ikhtilaf in Islamic law with special reference to the shafi'i school. Islamic Studies, 34(4), 367-384.

Basedau, M., Gobien, S. \& Prediger, S. (2017). The ambivalent role of religion for sustainable development: A review of the empirical evidence. German Institute of Global and Area Studies.

Bhalotra, S., Clots-Figueras, I., Cassan, G., \& Iyer, L. (2014). Religion, politician identity and development outcomes: Evidence from India. Journal of Economic Behavior \& Organization, 104, 4-17.

Caliendo, M., Fossen, F., \& Kritikos, A. (2012). Trust, positive reciprocity, and negative reciprocity: Do these traits impact entrepreneurial dynamics?. Journal of Economic Psychology, 33(2), 394409.

Croes, R., Ridderstaat, J., Bąk, M., \& Zientara, P. (2021). Tourism specialization, economic growth, human development and transition economies: The case of Poland. Tourism Management, 82, $1-12$.

Cysne, R. P. (2006). On the positive correlation between income and patience. Revista Brasileira de Economia, 60(1), 21-32.

da Silva, J. M. C., de Castro Dias, T. C. A., da Cunha, A. C., \& Cunha, H. F. A. (2021). Funding deficits of protected areas in Brazil. Land Use Policy, 100, 1-6.

Datta, S. K. \& Singh, K. (2019). Variation and determinants of financial inclusion and their association with human development: A cross-country analysis. IIMB Management Review, 31(4), 336-349.

Deneulin, S. \& Rakodi, C. (2011). Revisiting religion: Development studies thirty years on. World Development, 39(1), 45-54.

Deneulin, S. \& Zampini-Davies, A. (2017). Engaging development and religion: Methodological groundings. World Development, 99, 110-121.

Eadington, W. R. (2003). Measuring costs from permitted gaming: Concepts and categories in evaluating gambling's consequences. Journal of Gambling Studies, 19(2), 185-213.

Falk, A., Becker, A., Dohmen, T., Enke, B., Huffman, D., \& Sunde, U. (2018). Global evidence on economic preferences. The Quarterly Journal of Economics, 133(4), 1645-1692.

Fehr, E., \& Gächter, S. (2000). Fairness and retaliation: The economics of reciprocity. Journal of economic perspectives, 14(3), 159-181.

Gamlath, S. (2013). The governance dimension of human development. Humanomics, 29(4), 240-259.

Gujarati, D. N. \& Porter, D. C. (2008). Basic Econometrics (5th ed.). New York (US), McGrawHill/Irwin.

Hadfield, G. K. (2008). The levers of legal design: Institutional determinants of the quality of law. Journal of Comparative Economics, 36(1), 43-73.

Hafner, K. A., \& Mayer-Foulkes, D. (2013). Fertility, economic growth, and human development causal determinants of the developed lifestyle. Journal of Macroeconomics, 38, 107-120.

Herold, F. (2010). Contractual incompleteness as a signal of trust. Games and Economic Behavior, 68(1), 180-191.

Kailani, N., \& Slama, M. (2020). Accelerating Islamic charities in Indonesia: Zakat, sedekah and the immediacy of social media. South East Asia Research, 28(1), 70-86.

Kurtulmuş, B. E., \& Warner, B. (2016). Informal institutional framework and entrepreneurial strategic 
orientation: the role of religion. International Journal of Entrepreneurship and Innovation Management, 20(3-4), 160-173.

Leaman, O. (2006). The Qur'an: An Encyclopedia. New York (US), Routledge.

Lumineau, F. (2017). How contracts influence trust and distrust. Journal of Management, 43(5), 1553-1577.

Mantell, E. H. (2018). An economic theory of altruism based on rankings in a stable social hierarchy. International Review of Economics, 65(4), 421-447.

Maski, G., Kafabih, A. and Hoetoro, A. (2018). Testing profit and loss sharing to stabilise level of inflation : Evidence from Indonesia. Research in World Economy, 9(2), 12-23.

McClave, J. \& Sincich, T. (2018). Statistics (13th ed.). Harlow (UK), Pearson Education.

Mirakhor, A. \& Askari, H. (2010). Islam and the Path to Human and Economic Development. New York (US), Palgrave Macmillan.

Myers, C. (2017). Three Reasons Why Should be Patient in Business [online]. Retrieved 2020 Sept 9 from https://www.forbes.com/sites/chrismyers/2017/06/02/three-reasons-why-you-should-bepatient-in-business/\#37a19af55adc.

Nasr, S. H., Dagli, C. K., Dakake, M. M., Lumbard, J. E., \& Rustom, M. (2015). The Study Quran. A new translation and commentary, 19.

Nooteboom, G. (2015). Living dangerously oplosan, gambling and competition as everyday risktaking in Java and East Kalimantan Indonesia. Disaster Prevention and Management, 24(4), 523-538.

Palanca, E. H. (1986). Religion and Economic Development. Philippine Studies, 34(2), 162-180.

Saito, K. (2015). Impure altruism and impure selfishness. Journal of Economic Theory, 158, 336-370.

Salaghe, F., Sundali, J., Nichols, M. W., \& Guerrero, F. (2020). An empirical investigation of wagering behavior in a large sample of slot machine gamblers. Journal of Economic Behavior \& Organization, 169, 369-388.

Sarkodie, S. A. and Adams, S. (2020). Electricity access, human development index, governance and income inequality in Sub-Sahara Africa. Energy Report, 6, 455-466.

Schwartz, S. H. (1994). Are there universal aspect in the structure and contents of human values?. Journal of Social Issue, 50(4), 19-45.

Sinha, A. \& Sengupta, T. (2019). Impact of natural resource rents on human development: What is the role of globalization in Asia Pacific countries?. Resources Policy, 63, 1-9.

Suzuki, Y. \& Miah, M.D. (2016). Altruism, reciprocity, and Islamic equity finance. International Journal of Islamic and Middle Eastern Finance and Management, 9(2), 205-221.

Todaro, M. P. \& Smith, S.C. (2012). Economic Development (11th ed.). Boston (US), Pearson.

Uddin, M.A. (2015). Principles of Islamic finance: Prohibition of riba, gharar and maysir. Munich Personal RePEc Archive, No. 67711, 09 Nov 2015.

Varian, H. R. (2014), Intermediate Microeconomics: A Modern Approach (9th ed.). New York (US), W. W. Norton \& Company.

Yaroub, A., Zuhair, M. \& Sahib, N.A. (2019). Enhancing Islamic concepts through English children's lterature: Al-Ibtila, the test of patience. Opcion, 35(19), 2489-2504.

Yolanda, Sari I. P., Mulatsih, S. N., \& Massora A. (2020). The human development and poverty alleviation based on klassen's typology: Case study of east java province. Journal of Advance Research in Dynamic and Control Systems, 12(7), 477-483. 